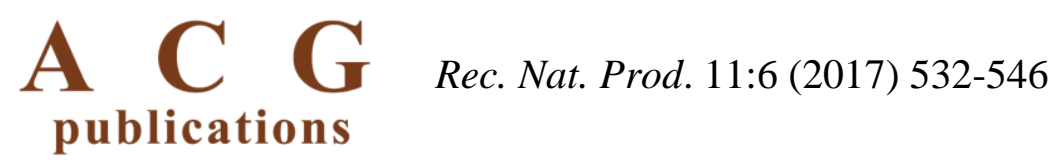

records of natural products

\title{
The Flavonoid Fraction from Rhoeo discolor Leaves Acting as Antiviral Against Influenza A Virus
}

\author{
Yazmin Sánchez-Roque ${ }^{1}$, Guadalupe Ayora-Talavera ${ }^{2}$, Reiner Rincón- \\ Rosales ${ }^{1}$, Federico Antonio Gutiérrez-Miceli ${ }^{1}$, Rocío Meza-Gordillo ${ }^{1}$, \\ Robert Winkler ${ }^{3}$, Roberto Gamboa-Becerra ${ }^{3}$, \\ Teresa del Rosario Ayora-Talavera ${ }^{4}$ and Víctor Manuel Ruiz-Valdiviezo ${ }^{*}$ \\ ${ }^{1}$ Laboratory of Biotechnology, Instituto Tecnológico de Tuxtla Gutiérrez, Carretera Panamericana \\ km 1080, C.P. 29050, Tuxtla Gutiérrez, Chiapas, México \\ ${ }^{2}$ Laboratory of Virology, Centro de Investigaciones Regionales Dr. Hideyo Noguchi, Universidad \\ Autónoma de Yucatán. Av. Itzaes 490, C.P. 97000, Mérida, Yucatán, México \\ ${ }^{3}$ CINVESTAV, Unidad Irapuato, Department of Biotechnology \& Biochemistry, Km 9.6 Libramiento \\ Norte Carretera Irapuato-León 36821 Km 9.6, C.P.36821, Irapuato, Guanajuato, México \\ ${ }^{4}$ Centro de Investigación y Asistencia en Tecnología y Diseño del Estado de Jalisco, Unidad Sureste. \\ Km 5.5 Sierra Papacal-Chuburná Puerto, 97302, Mérida, Yucatán, México
}

(Received January 14, 2017; Revised May 17, 2017; Accepted May 24, 2017)

\begin{abstract}
In vitro antiviral effect of a crude methanol extract and six fractions isolated from Rhoeo discolor against pandemic influenza $A(H 1 N 1)$ was evaluated in this study. The phytochemical analysis to identify the main classes of secondary metabolites was performed by thin layer chromatography (TLC). The cytotoxic effect and cell viability was determined in MDCK cells, and the antiviral activity was evaluated by qRT-PCR to detect influenza virus nucleoprotein (NP) gene. Finally a metabolomic analysis was performed using UPLC-MS. The phytochemical analysis revealed the presence of coumarins, tannins, saponins and flavonoids in the methanol extracts. Cytotoxicity related to $50 \%$ cell viability indicated concentrations of $<1 \mu \mathrm{g} / \mathrm{mL}$ for the six fractions tested and $>1 \mu \mathrm{g} / \mathrm{mL}$ for the crude extracts. Fraction MF1 inhibited synthesis of viral NP at co-treatment level at a concentration of $0.30 \pm 0.02 \mathrm{~g} / \mathrm{mL}$ with a selectivity index (SI) of 30 . The metabolomic analysis identified the presence of five flavonoids kaempferol, quercetin, isoquercetin luteolin-5-glucoside and rutin. Antiviral activity of flavonoids from $R$. discolor against the influenza A (H1N1) virus are reported for the first time.
\end{abstract}

Keywords: Antiviral agent; flavonoids; in vitro; hemagglutinin; real-time PCR; metabolite. (C) 2017 ACG Publications. All rights reserved.

\section{Introduction}

The H1N1 influenza A virus is responsible for seasonal flu epidemics and the main cause of a highly contagious respiratory infection [1, 2]. Currently, even though H1N1 influenza A viruses occasionally infect humans, vaccination is the first option to mitigate influenza infection and to reduce the impact of the epidemics. In addition, antiviral drugs provide a fundamental complementary line of defense, particularly against the fast-spreading pandemic influenza A virus strains, especially where

\footnotetext{
* Corresponding author. E-mail: bioqvic@ hotmail.com Phone: +52 (961) 6150461; fax: +52 (961) 6151687.
} 
vaccines might be not available on time $[3,4]$.

Only two classes of anti-influenza virus drugs are currently accessible. Until now, there are only four antiviral agents approved by the FDA to treat an influenza virus infection, and these can be divided into two groups. The group comprising of amantadine and rimantadine to block the M2 ion channel, and the group of zanamivir and oseltamivir to inhibit the viral neuraminidase which plays an important role in virus release [5]. The emergence of influenza A strains that are resistant to these two classes of antiviral drugs highlights the need for additional antiviral drugs against these pathogens. Besides these two major groups of anti-influenza drugs, several other approaches exist, such as: inhibition of viral RNA transcription (RNA polymerase), small interfering RNA, inhibition of virus cell fusion, and proteolytic processing of hemagglutinin (HA) [6-8]. Even though several antiviral compounds have been developed against influenza virus, their long-term efficacy is often limited due to toxicity or the emergence of drug-resistant virus mutations.

Phenolic compounds, or polyphenols, constitute one of the most numerous and widely distributed groups of substances in the plant kingdom, with more than 8000 phenolic structures currently known. Polyphenols are products of the secondary metabolism of plants. The structure of natural polyphenols varies from simple molecules, such as phenolic acids, to highly polymerized compounds [9]. Polyphenols exhibit a wide range of biological effects [10-12]. Bioavailability differs greatly from one polyphenol to another [13]. The knowledge of absorption, bio-distribution and metabolism of polyphenols is partial and incomplete. Some polyphenols like flavonoids have antiviral activities [14-16]. These studies reported antiviral and antibacterial potential and the mode of action of polyphenols [17], including several reports describing the antiviral activity of polyphenols against the influenza virus. The emergence of drug-resistant strains highlights the need to develop novel antiviral drugs that effectively target other viral proteins or cellular factors involved in the influenza virus life cycle. These resistant strains could cause outbreaks in the future, so the development of new antiinfluenza drugs is vitally important. The use of medicinal plants such as Rhoeo discolor is a viable alternative.

Rhoeo discolor L. H'er Hance [syn. Tradescantia spathacea Swartz, Rhoeo spathacea (Swartz) Stearn], is a Mexican plant that is used in traditional medicine [18]. This plant belongs to the Commelinaceae family and can be found in the Caribbean and Central America [19]. In the Southeast of Mexico, it is known as Maguey Morado (Purple Maguey). This plant has a rich folkloric reputation as antiviral and antimicrobial agent, and to the best of our knowledge, no previous scientific reports about its antiviral activity are available [20,21]. Some chemicals detected in Rhoeo discolor by traditional methods are flavonoids, anthocyanins, saponins, carotenoids, waxes, terpenoids, coumarinic and steroidal compounds [22,23]. When we evaluated Rhoeo discolor's ethanolic crude extract in an in vitro system, it showed antimutagenic, antigenotoxic and antioxidative activities [24,25]. To our knowledge, this report is the first study that evaluates the toxic effect of flavonoids present in the methanol extracts and their fractions obtained from leaves of $R$. discolor on animal epithelial cell culture and its antiviral activity against influenza virus A (H1N1).

\section{Materials and Methods}

\subsection{Plant Material}

The leaves of Rhoeo discolor were collected during the first 5 days of bloom in Tuxtla Gutiérrez, Chiapas, México. This plant is deposited in the herbarium 'MEXU (Herbario Nacional de México de la Universidad Nacional Autónoma de México)' with the number of deposit PVsn16584 and in the Integrated Taxonomic Information System (ITIS Report) with the Taxonomic Serial No.: 505554 and Global Biodiversity Information Facility (GBIF) with taxon ID 10208304. The geographic location was latitude $16^{\circ} 45^{\prime} 11^{\prime \prime}$ north and longitude $93^{\circ} 06^{\prime} 56^{\prime \prime}$, corresponding to tropical regions, with more than $1100 \mathrm{~mm}$ of annual rainfall. The leaves were air-dried and ground in a laboratory mill. The dried samples were stored at room temperature, in closed containers and in the dark, until used. 


\subsection{Preparation of Rhoeo discolor Extracts and Fractions}

$20 \mathrm{~g}$ of dried $R$. discolor leaves were added to $450 \mathrm{~mL}$ of $100 \%$ methanol (Sigma-Aldrich); the mixture was then sonicated using a Bandelin SONOREX ${ }^{\mathrm{TM}}$ Digital Ultrasonic bath $10 \mathrm{P}$, at room temperature during $2 \mathrm{~h}$. Afterwards, the mixture was filtered and centrifuged (Thermo scientific, SHKA $\left.{ }^{\circledR} 200\right)$ at $3000 \mathrm{rpm}$ during 10 minutes. The supernatant was evaporated under vacuum in a rotary evaporator (Rotavapor R-215) at a temperature of $45^{\circ} \mathrm{C}$ and the residue was then suspended in 5 $\mathrm{ml}$ of methanol and stored at $-20^{\circ} \mathrm{C}$. The fractions were obtained by plates of silica gel $60 \mathrm{~F}_{254}$ Merck using a hybrid technique based on methods described previously [26-28]. Briefly, a saturation chamber (MegaLab) was filled with the solvent system chloroform (Avantor): methanol (Sigma): ammonium hydroxide (Avantor) (85:14:1). Subsequently, the chromatogram were divided into sections and each was scraped, at which point the powder obtained from each fraction was suspended in $5 \mathrm{~mL}$ of methanol, vortexed (Vortex IKA® GENIUS 3) for 2 hours, and centrifuged to $3000 \mathrm{rpm}$ for $5 \mathrm{~min}$. Finally, the fractions were stored at $-20^{\circ} \mathrm{C}$ and protected from light.

\subsection{Phytochemical Analysis}

The qualitative analysis was performed through a chemical analysis for detects the presence of main classes of secondary metabolites. It was determined using a silica gel thin-layer chromatography (TLC), reported by Harbone [29]. Briefly, the chamber was saturated with mobile phase hexane (HYCEL): ethyl acetate (HYCEL): acetic acid (Avantor) (31: 14: 5). After that, the stationary phase plates silica gel $60 \mathrm{~F}_{254} 10 \mathrm{X} 20 \mathrm{~cm}$ aluminum base (Merck) were placed in the chamber. The standards of metabolite: developer reagent (flavonoids: quercetin: Citroboric reagent; Coumarin: umbelliferone: $5 \% \mathrm{KOH}$ in ethane; Saponin: diosgenin: $5 \% \mathrm{H}_{2} \mathrm{SO}_{4}$ in methanol, Tannins: proanthocyanidins: Vanillin $5 \% \mathrm{HCl}$ ) were used. Thus, the components were eluded during 20 minutes and were observed through a UV chamber, 245-365 nm (Chromato-Vue ${ }^{\circledR}$ C-75).

The quantitative analysis was done using a visible light spectrophotometer (DR5000-03 HACHUSA) [29]. Total phenols content was estimated as gallic acid equivalents [30]. The saponins content was estimated as diosgenin equivalents [31]. Flavones and flavonols were estimated as quercetin equivalents [26]. The total flavonoids content was estimated as rutin equivalents [32]. The tannins content was estimated as equivalent to proanthocyanidin [33]. Finally, the Coumarin content was estimated as equivalent to umbelliferone [34].

\subsection{Lyophilization of MF1 fraction}

Once the MF1 fraction solvent methanolic was placed in a water bath at $45{ }^{\circ} \mathrm{C}$ until the methanol evaporated at $99 \%$. The remaining $1 \%$ was re-suspended in distilled water in order to freeze the sample, and finally was freeze-dried in a lyophilizer under a pressure of $5 \mathrm{mmHg}$ at $-50{ }^{\circ} \mathrm{C}$ (LABCONCO FreeZone 4.5, Kansas City, USA.) [35].

\subsection{UPLC-MS analysis}

\subsubsection{Metabolite Extraction}

$20 \mathrm{mg}$ of the freeze-dried sample was dissolved in $500 \mu \mathrm{L}$ of absolute methanol for 10 minutes in an ultrasound bath at room temperature. Samples were filtered using a $0.2 \mu \mathrm{m}$ Nylon membrane and were subjected to UPLC-MS analysis.

\subsubsection{Identification by HPLC-ESI-MS/MS}

The UPLC-MS analysis was performed with the HPLC-ESI-MS/MS system (LCQ Fleet Ion trap mass spectrometer, Thermo Finnigan, San Jose, CA, USA), using a hypersil gold C18 column (50 
x $2.1 \mathrm{~mm}, 1.9 \mu \mathrm{m})$. Briefly, the conditions were the following: the mobile phase $\mathrm{H}_{2} \mathrm{O}$ with $0.1 \%(\mathrm{v} / \mathrm{v})$ formic acid (solvent A); solvent B: methanol with $0.1 \%$ formic acid, oven column temperature: $38^{\circ} \mathrm{C}$, with injection volume at $10 \mu \mathrm{L}$. Flow rate: $350 \mu \mathrm{L} / \mathrm{min}$ and solvent gradient: $35 \% \mathrm{~B}, 0-1.5 \mathrm{~min} ; 35$ $86 \%$ B , 1.5-3 min; 86-100\%B, 3-25 min; 100\%B, 25-27min; 100\%B-35\%B, 27-27.5; column re equilibration for 1.5 minutes (27.5-29 $\mathrm{min})$ with $35 \% \mathrm{~B}$ [36].

\subsection{Cells and Viruses}

Madin-Darby canine kidney (MDCK) cells (ATCC, Manassas,VA) were grown in Dulbecco's Modified Eagle's Medium (DMEM, Sigma-Aldrich, St Louis, MO, USA) supplemented with 10\% fetal bovine serum (FBS; Invitrogen), $100 \mathrm{U} / \mathrm{mL}$ penicillin, and $100 \mu \mathrm{g} / \mathrm{mL}$ streptomycin at $37^{\circ} \mathrm{C}$ [37]. Influenza virus strains A/Yucatan/2370 (H1N1) were obtained from the Laboratorio de Virología del Centro de Investigaciones Dr. Hideyo Inoguchi Institute in Mérida, Yucatán, México. These strains were propagated in MDCK cells at $37{ }^{\circ} \mathrm{C}$ in $5 \% \mathrm{CO}_{2}$ [38].

\subsection{Cytotoxicity Assays}

MDCK cells were grown in 96 well plates at a cell density of $1 \times 10^{5}$ cells per well for $24 \mathrm{~h}$ at 37 ${ }^{\circ} \mathrm{C}$ in $5 \% \mathrm{CO}_{2}$. The medium was removed; cells were washed twice with $1 \mathrm{X}$ Phosphate Buffer Solution (PBS) pH 7.2 and incubated with serial dilutions of extracts and fractions for $72 \mathrm{~h}$ at $37^{\circ} \mathrm{C}$ in $5 \% \mathrm{CO}_{2}$. Then, the inoculum was replaced with media and $5 \mu \mathrm{L}$ MTT (3-[4,5-dimethylthiozol-2-yl]2,5-diphenyltetrazolium bromide (Sigma, St. Louis, MO) and incubated at $37^{\circ} \mathrm{C}$ during $4 \mathrm{~h}$. The supernatant was removed, and formazan crystals were solubilized with $100 \mu \mathrm{L} 0.04 \mathrm{M} \mathrm{HCl}$ isopropanol. Finally, a 50\% cytotoxic concentration $\left(\mathrm{CC}_{50}\right)$ was determined using the spectrophotometric method described by Shih et al. [39]

\subsection{Antiviral Assay}

Pre-treatment assay: MDCK cells were grown in 96 well plates at a cell density of $1 \times 10^{5}$ cells per well during $24 \mathrm{~h}$ at $37^{\circ} \mathrm{C}$ in $5 \% \mathrm{CO}_{2}$. Cells were washed twice with $1 \mathrm{X}$ PBS and incubated for 12 $\mathrm{h}$ with the non-cytotoxic concentration $(\leq \mathrm{CC} 50)$ from both the crude extract and the six fractions. Then, extracts and fractions were removed and MDCK cells were washed twice with 1X PBS, and inoculated with H1N1 influenza virus at a multiplicity of infection (MOI) of 0.01 during $1 \mathrm{~h}$ with occasional rocking. The virus was removed and the cells were incubated with DMEM supplemented with $2 \mu \mathrm{g} / \mathrm{mL}$ TPCK-trypsin [10].

Co-treatment assay: All concentrations of extracts and fractions were mixed with the virus and incubated at $4^{\circ} \mathrm{C}$ for $1 \mathrm{~h}$. The mixture was inoculated on a confluent monolayer of MDCK cells previously seeded at $1 \times 10^{5}$ cells per well and incubated for $1 \mathrm{~h}$ at room temperature with occasional shaking. The mixture virus:extract/fraction was removed and cells incubated for $72 \mathrm{~h}$ at $37^{\circ} \mathrm{C}$ in $5 \%$ $\mathrm{CO}_{2}$ with DMEM supplemented with $2 \mu \mathrm{g} / \mathrm{mL}$ of TPCK-trypsin [11].

Post-treatment assay: The influenza virus at a MOI of 0.01 was inoculated on the confluent MDCK cell monolayers ( $1 \times 10^{5}$ cells per well) for $1 \mathrm{~h}$ with occasional rocking [5]. The media was removed and replaced by DMEM containing $10 \mu \mathrm{g} / \mathrm{mL}$ trypsin and several extracts and fractions at different concentrations for each treatment. The cultures were later incubated for $72 \mathrm{~h}$ at $37^{\circ} \mathrm{C}$, under a $5 \% \mathrm{CO}_{2}$ atmosphere, until the infected cells under untreated control showed complete viral cytopathic effect (CPE) when observed by light microscopy [10]. For all assays, after the $72 \mathrm{~h}$ incubation period, cells were washed twice with sterile PBS and stained with a $0.4 \%$ crystal violet solution in distilled water. The samples were incubated for 30min at room temperature and the crystal violet solution was removed and the cells were washed twice with $1 \mathrm{X}$ PBS (pH 7.4) and stained with $0.4 \%$ crystal violet in methanol. Absorbance was measured at $540 \mathrm{~nm}$ using a microplate reader and Selectivity Index (SI) was calculated by the ratio of $\mathrm{TC}_{50} / \mathrm{EC}_{50}[40]$ (Figure 1). 

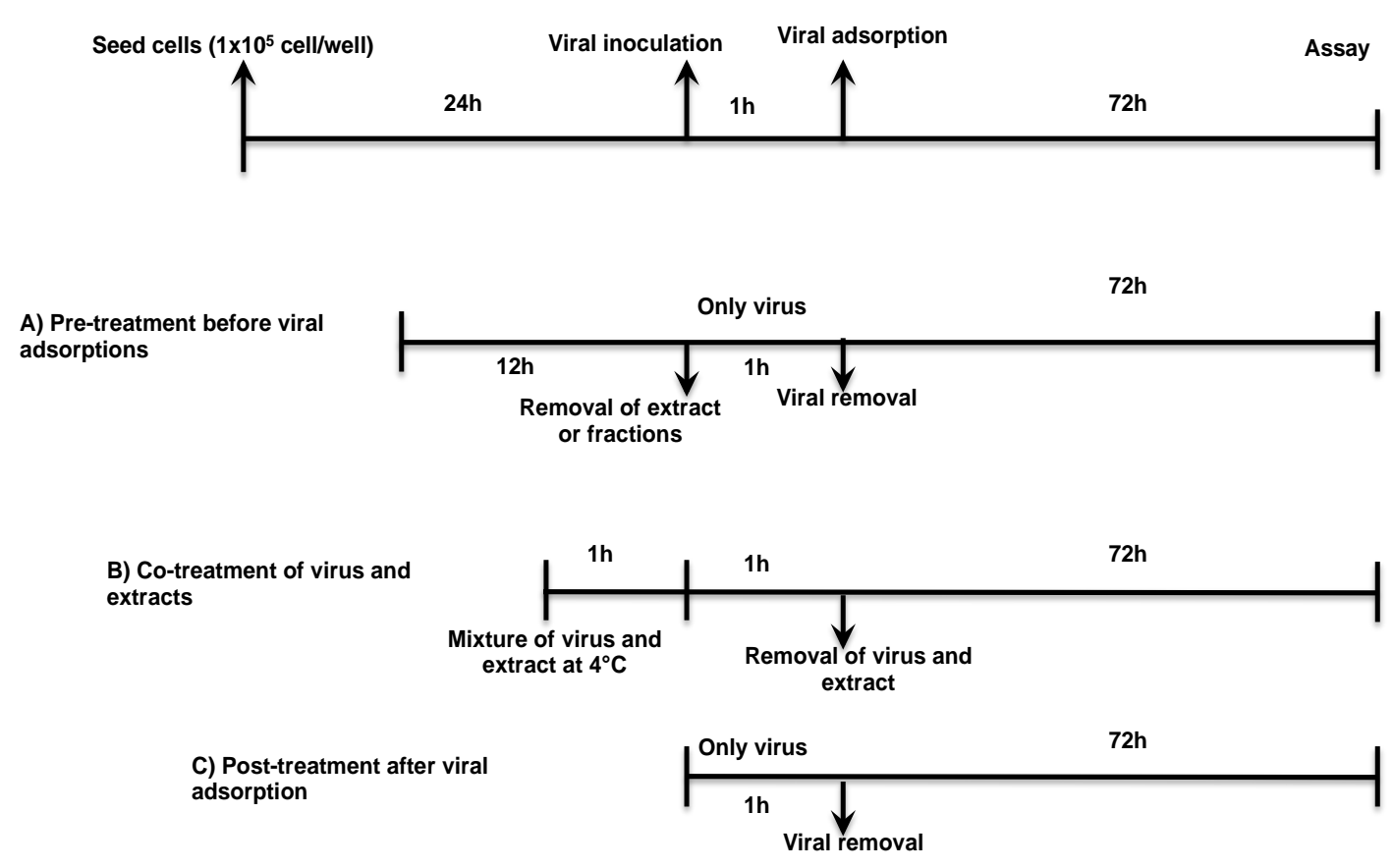

Figure 1. Antiviral assays strategy with $R$. discolor extracts and fractions on different stages of virus infection. MDCK cells were incubated $12 \mathrm{~h}$ prior to virus infection for pre-treatment assay (A), or with a mixture of virus:extract/fraction previously incubated at $4{ }^{\circ} \mathrm{C}$ for $1 \mathrm{~h}$ as co-treatment assay (B), or during $72 \mathrm{~h}$ after viral infection for post treatment assay (C).

\subsection{Inhibition Assay of Binding and Entry in MDCK Cells}

MDCK cells were grown in 12 well plates at a cell density of $1 \times 10^{6}$ cells per well for $24 \mathrm{~h}$, then the plates were incubated overnight at $37^{\circ} \mathrm{C}$ under $5 \% \mathrm{CO}_{2}$. Medium was removed and the cells were washed once with PBS. In all treatments, the virus-fractions and virus-6'SLN (6-sialyl (Nacetylactosamine)) (positive control). The mixtures were collected and stored at $-80{ }^{\circ} \mathrm{C}$ until use to determine viral titers with a plaque assay to measure the plaque-forming units [42].

\subsection{Plaque Reduction Assay (PRA)}

MDCK cells $\left(2 \times 10^{5}\right.$ cells per well $)$ were seeded into 12 -well culture plates and incubated overnight. The cells were washed twice with $1 \mathrm{X}$ PBS and infected with supernantants collected from the inhibition assay: After, $1 \mathrm{~h}$ incubation at room temperature, viral inoculum was removed and cells were incubated with $3 \%$ slow-melting agarose overlay medium at $37^{\circ} \mathrm{C}$ under $5 \% \mathrm{CO}_{2}$ for $72 \mathrm{~h}$. Cells were stained with $0.4 \%$ crystal violet in methanol. Viral titers were determined by plaque couting [41]. The assays were run in triplicate and in three independent experiments.

\subsection{RNA Extraction and Quantitative RT-PCR ( $q R T-P C R)$}

MDCK cells were grown in 6 well plates at $5 \times 10^{5}$ cells per well for $24 \mathrm{~h}$ and incubated overnight at $37^{\circ} \mathrm{C}$ under $5 \% \mathrm{CO}_{2}$. The medium was removed and the cells washed once with PBS. Then, the mix of virus-fraction and virus- 6'SLN (6'-Sialyl-N-acetyllactosamine)) were added to the confluent monolar (positive control). The cells were infected with influenza virus A/Yucatán/2370 $(\mathrm{MOI}=0.01)$ for $1 \mathrm{~h}$. Then the cells were harvested at $72 \mathrm{~h}$ postinfection (pi) and their total RNA was extracted with extraction kit (ROCHE Magna Pure Compact RNA Isolation) according to the manufacturer's instructions. The RNA was recovered and stored at $-80^{\circ} \mathrm{C}$. 
NP gene expression of the influenza virus was detected and quantified using qRT-PCR real-time [43]. Briefly, we used oligonucleotides forward 5'GCA CGG TCA GCA CTT ATY CTR AG 3'; revers 5'GTG RGC TGG GTT TTC ATT TGG TC3' and probes of hydrolysis (Taqman) probe 5'/ 56FAM CYA CTG CAA GCC CA/BHQ_1DT/ located double labeled. These oligonucleotides were designed for universal detection of influenza virus type A/H1N1pdm09. The quantification of the NP gene was done using the quantitative Kit qRT-PCR (One-Step Invitrogen SuperScript ${ }^{\mathrm{TM}}$ III Platinum One-Step) $[44,45]$.

\subsection{Statistical Analysis}

Data is presented as mean \pm standard deviation. For statistical analyses one-way ANOVA was used at $\mathrm{p}<0.05$ level of significance, with the STATGRAPHICS PLUS program (1999).

\section{Results and Discussion}

The phytochemical composition of crude extracts of $R$. discolor leaves was determined. The saponins content $(10.3 \mathrm{mg} / \mathrm{g})$ and the concentration of total phenols $(2.3 \mathrm{mg} / \mathrm{g})$ were higher compared with the content values of tannins $(0.7 \mathrm{mg} / \mathrm{g})$, flavonoids $(0.7 \mathrm{mg} / \mathrm{g})$ and coumarins $(0.5 \mathrm{mg} / \mathrm{g})$.

The cytotoxicity of $R$. discolor extracts and the six fractions were evaluated by the MTT assay for a 50\% cytotoxic concentration (CC50). Half of the maximal cytotoxic concentration (CC50) was $4.90 \mu \mathrm{g} / \mathrm{mL}$ for the crude extract obtained, while the CC50 of fractions MF1, MF2, and MF3 were found in a range of 0.60 to $0.90 \mu \mathrm{g} / \mathrm{mL}$. The fractions MF4, MF5 and MF6 showed CC50 values of 0.60 to $0.70 \mu \mathrm{g} / \mathrm{mL}$ (Table 1). These results indicate that antiviral effect was carried out when $R$. discolor extracts and fractions concentration below CC50 were evaluated.

Table 1. Cytotoxic and antiviral activities against H1N1 of Rhoeo discolor crude extract and fractions in the co-treatment and post-treatment

\begin{tabular}{llllll}
\hline & \multicolumn{3}{c}{ Co-treatment } & \multicolumn{2}{c}{ Pos-treatment } \\
\hline Fractions & $\begin{array}{c}\mathrm{CC} 50 \\
(\mu \mathrm{g} / \mathrm{mL})\end{array}$ & $\begin{array}{c}\mathrm{IC} 50 \\
(\mu \mathrm{g} / \mathrm{mL})\end{array}$ & SI (CC50/IC50) & $\begin{array}{c}\mathrm{IC50} \\
(\mu \mathrm{g} / \mathrm{mL})\end{array}$ & SI (CC50/IC50) \\
Crude extract & $4.90^{\mathrm{a}} \pm 0.04$ & $>\mathrm{IC} 50$ & 0 & $>\mathrm{IC} 50$ & 0 \\
MF1 & $0.90 \pm 0.01^{\mathrm{b}}$ & $0.30 \pm 0.02$ & 30 & $0.20 \pm 0.08$ & 4.5 \\
MF2 & $0.70 \pm 0.01$ & $0.40 \pm 0.06$ & 1.75 & $0.70 \pm 0.17$ & 1 \\
MF3 & $0.60 \pm 0.02$ & $>\mathrm{IC} 50$ & 0 & $>\mathrm{IC} 50$ & 0 \\
MF4 & $0.70 \pm 0.02$ & $0.20 \pm 0.10$ & 3.5 & $0.70 \pm 0.02$ & 1 \\
MF5 & $0.70 \pm 0.01$ & $0.70 \pm 0.15$ & 1 & $>\mathrm{IC} 50$ & 0 \\
MF6 & $0.60 \pm 0.00$ & $>\mathrm{IC} 50$ & 0 & $0.60 \pm 0.06$ & 1 \\
\hline
\end{tabular}

${ }^{a}$ Mean values of three replicates. ${ }^{b} \mathrm{SD}=$ standard deviation

CC50: Half maximal cytotoxic concentration.

IC50: Inhibitory concentration media, against (A/Yucatan/2370/09) after 72h of treatment with serial dilutions of antiviral compounds SI: Selectivity Index (SI= CC50 / IC50).

To determine the ability of extracts and fractions of $R$. discolor in preventing the infection of influenza virus to MDCK cells, we used and analyzed the pre-treatment and simultaneous treatment assays. The pre-treatment results showed that neither the fractions, nor the crude extracts had an antiviral effect against A/Yucatán/2370/90 (H1N1) in preventing the cytopathic effect of these cells by $50 \%$, even though we applied high concentrations. The viral and cellular controls allow for the detection of cytopathic effects and antiviral activity, therefore there is not a statistically significant difference between the percentage of cytopathic effect of each fraction and extract compared with viral control (Figure 2). The second assay is the co-treatment. Through this treatment, we assessed whether the fractions and extracts inhibit the virus for possible interactions with hemagglutinin. The crude extract showed no antiviral activity. On the other hand, the fractions of $R$. discolor did present activity, 
especially the MF1 fraction with a EC50 of $0.30 \pm 0.02 \mu \mathrm{g} / \mathrm{mL}$ obtained high values of index selective (30) (Table 1). These fractions prevent the entry of the virus into the cell. In the post-treatment stage, we evaluated the act of blocking the neuraminidase when the extract and the fractions were applied.

In this case, the crude extract did not show activity. However, the MF1, MF2, MF4, and MF6 fractions had concentrations of IC50 (Table 1). These results indicated that the fractions showed a low selectivity index, and therefore they are not promising for future research.

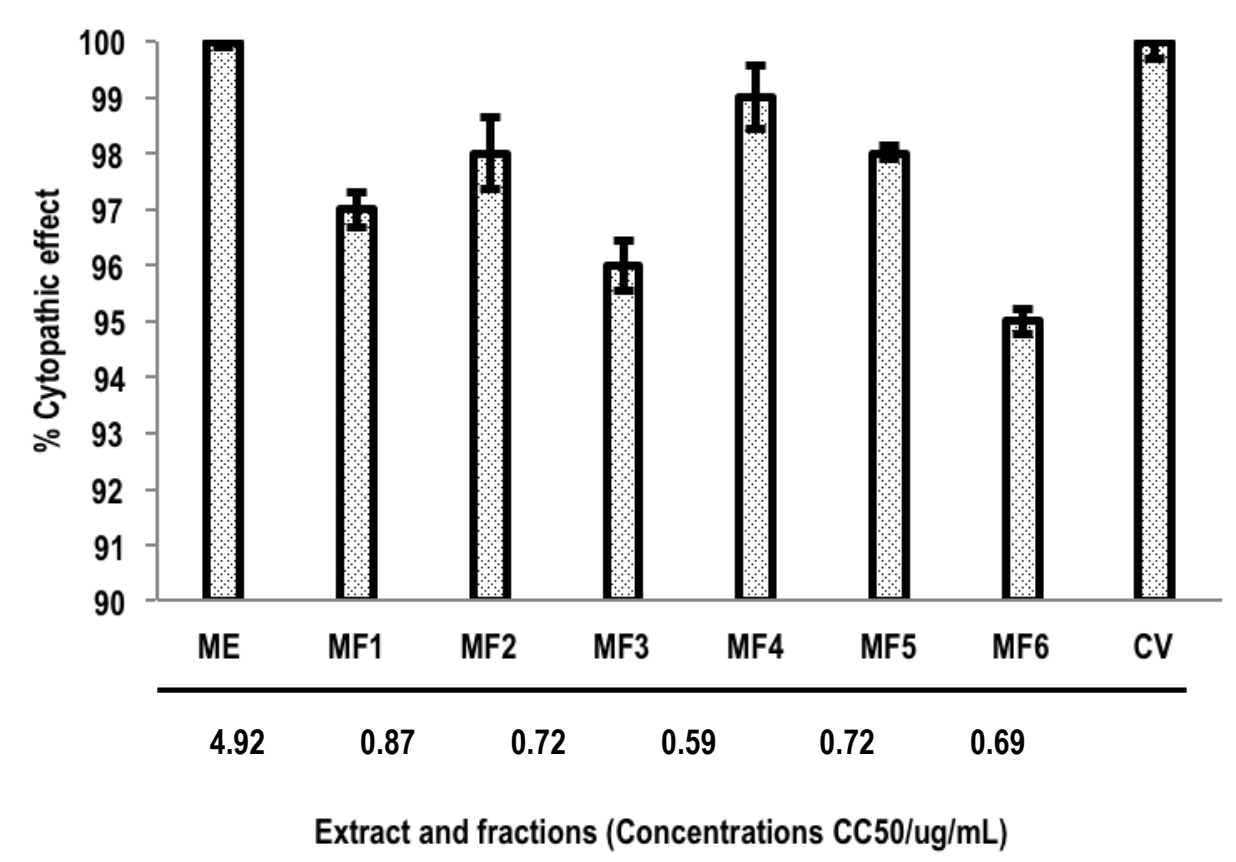

Figure 2. Percentage cytopathic effect of extracts and fractions of leaves of the plant $R$. discolor. Each fraction has CC50 values, Bars are \pm one standard deviation.

The aim of the experiment was to observe the Plaque Forming Units (PFU) caused by the viral replication. This assay was done in duplicate, and the virus was co-treated with the MF1 fraction and 6'SLN (positive control). The MF1 fraction was selected due to the fact that it shows the highest selectivity index (Table 1). The PFU was directly proportional to the time of co-treatment, and these results indicate that $100 \%$ of the inhibition was obtained after 60 minutes of treatment with the MF1 fraction and 6'SLN (Figure 3).

Additionally, it is very important to mention that the MF1 fraction inhibited the viral replication at 15 minutes and that the 6'SLN control was inhibited after 45 minutes. However, during the 15 to 30 minutes of co-treatment, 6'SLN and the MF1 fraction had a percentage of inhibition of 96.5 and 97.9 respectively, which shows that there is no statistically significant difference between the MF1 fraction and 6'SLN (positive control) (Figure 4).

The analysis of RNA expression was done by real-time PCR in order to verify if the MF1 fraction inhibits a co-treatment level. Only three samples were amplified. The first amplified sample was the viral control, with a number of copies of 2035.8; the second and third samples, which correspond to the virus co-treated with 6'SLN at 15 and 30 minutes, obtained a number of copies of 74.5 and 41.6 respectively. However, the virus co-treated with the MF1 fraction did not amplify, indicating an inhibition rate of $100 \%$ from the first 15 minutes (Table 2). 
Table 2. Copy number of the gene NP detected by qRT-PCR in real time of virus A/Yucatan/2370/09 co-treated with the MF1 fraction and 6'SLN (positive control).

\begin{tabular}{lllllll}
\hline Time & \multicolumn{2}{l}{ Number of copies } & \multicolumn{2}{l}{ Number of copies } & \% Inhibition \\
\hline (min) & MF1 & 6'SLN & CC & CV & MF1 & 6'SLN \\
$\mathbf{1 5}$ & 0 & 74.5 & 0 & 501.24 & 100 & 96.3 \\
$\mathbf{3 0}$ & 0 & 41.6 & 0 & $1,021.65$ & 100 & 97.9 \\
$\mathbf{4 5}$ & 0 & 0 & 0 & $1,612.43$ & 100 & 100 \\
$\mathbf{6 0}$ & 0 & 0 & 0 & $2,035.80$ & 100 & 100 \\
\hline
\end{tabular}

CV: Viral control.

CC: Cell control.

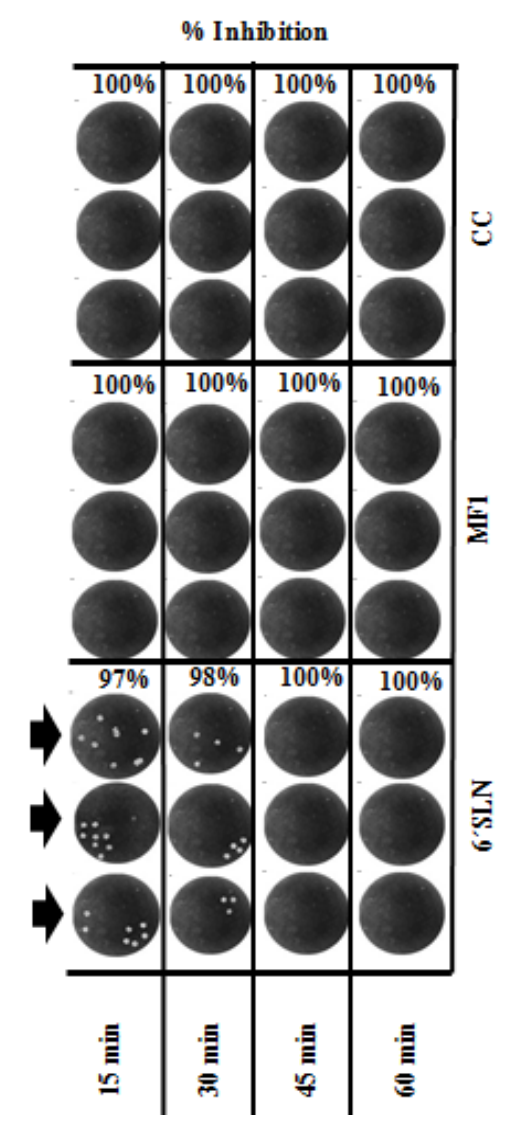

Figure 3. Plaque reduction assay of MF1 fraction and 6'SLN against influenza viruses. MDCK cells were infected with influenza viruses, including A/Yucatan/2370/09 at $0.01 \mathrm{MOI}$ for 15, 30, 45, and 60 min at $34^{\circ} \mathrm{C}$. After viral adsorption, cell monolayer was covered with overlay medium containing MF1 fractions and $6^{\prime} \mathrm{SLN}$ and further cultured at $34^{\circ} \mathrm{C}$ under $5 \% \mathrm{CO}_{2}$ for $48 \mathrm{~h}$. Then, the overlay medium was removed, and the cell monolayer was fixed with $10 \%$ formalin, stained with $1 \%$ crystal violet, and plaques were counted. 


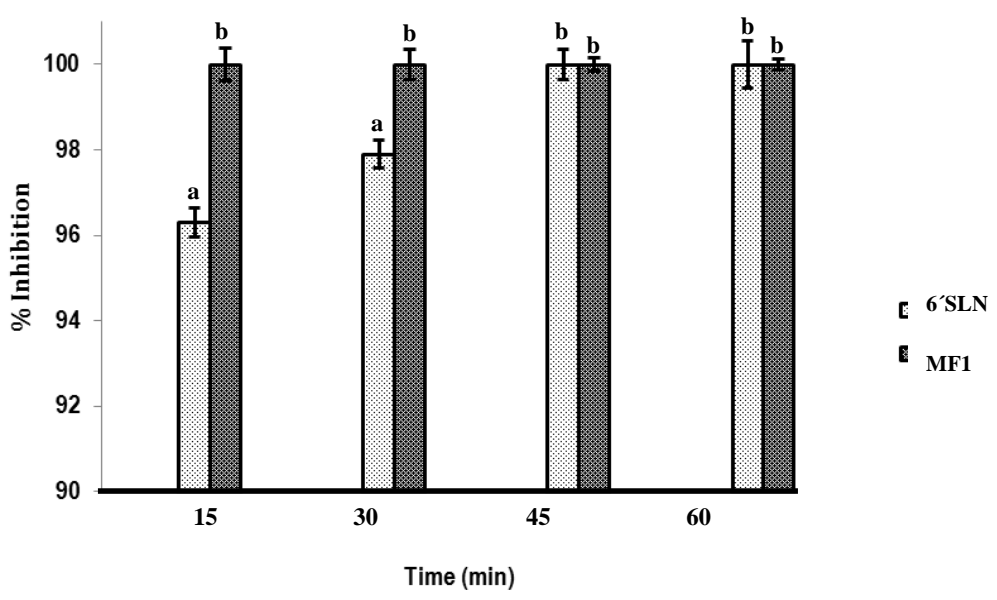

Figure 4. Percentage inhibition effect of the binding of the virus (A/Yucatan/2370/09) to the cell (MDCK). The cells were infected at a MOI $=0.01$ and co-treated with MF1 and 6'SLN. Bars are \pm one standard deviation. ${ }^{a}$ Mean values of three replicates, the means followed by the same letter are not significantly different $(p$-value $<0.05)$.

In order to perform quality control and determine the active components of the MF1 fractions, the UPLC-MS fingerprint chromatogram was established (Figure 5). The metabolomic analysis of the MF1 fraction showed the presence of five flavonoids, identified by their $m / z$ in a mass spectrum and concentration regarding their retention time (Table 3). The data analysis was done on the software MZmine 2.11, and the flavonoids identified were kaempferol, quercetine, isoquercetin, rutin, and luteolin-7-glucoside (Figure 6).

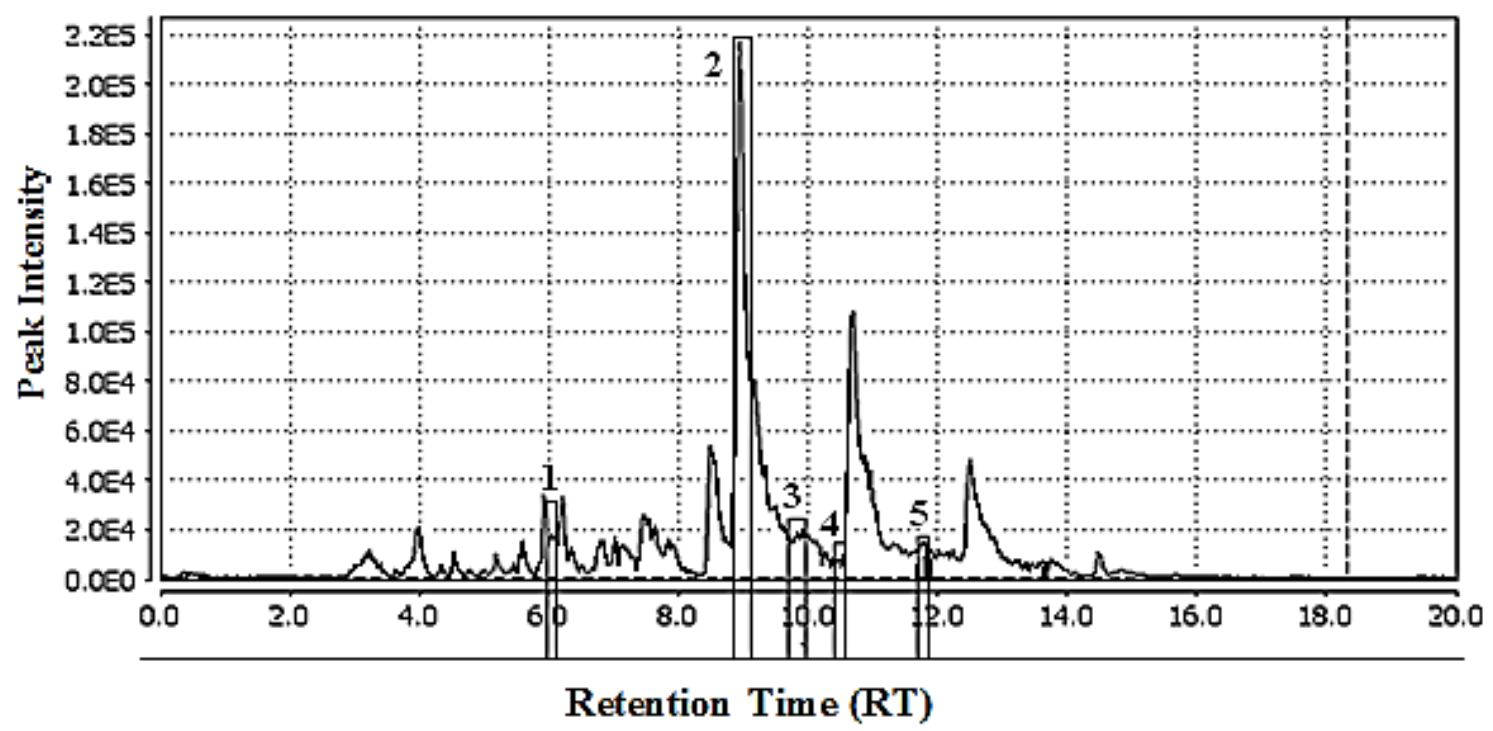

Figure 5. Metabolomic profile of the MF1 fraction obtained by UPLC-MS technique, chromatogram for reference flavonoids compounds: 1) luteolin-7-glucoside, 2) kaempferol, 3) isoquercetin, 4), quercetin 5) rutin 


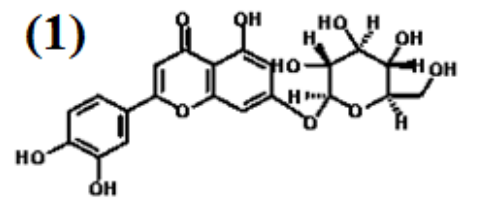<smiles>O=c1c(O)cc(O)cc2oc3cc(O)ccc3c(=O)c12</smiles>

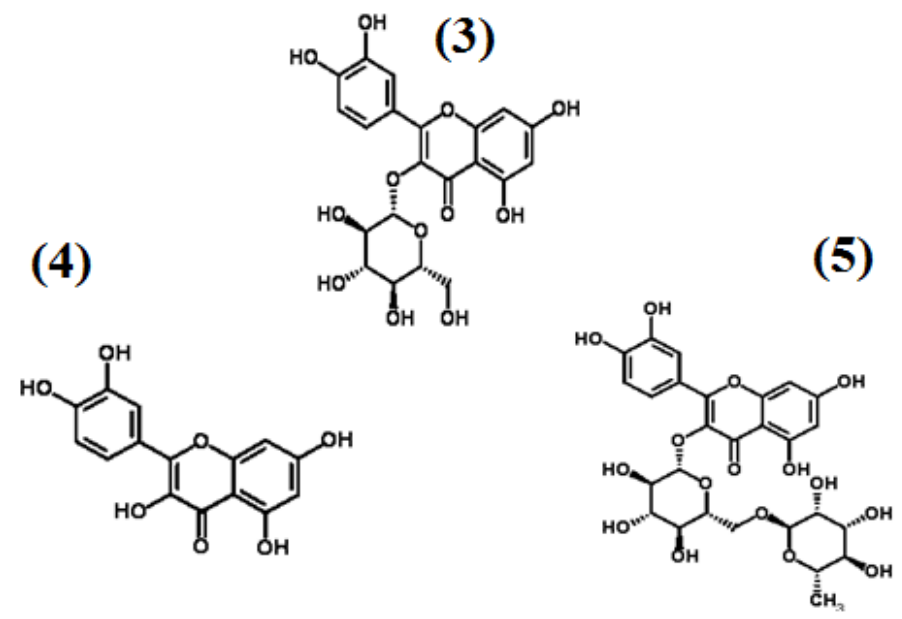

Figure 6. Chemical structure of the components identified in MF1 fraction 1) luteolin-7-glucoside, 2) kaempferol, 3) isoquercetin, 4) quercetin , 5) rutin from $R$. discolor.

Table 3. Phytochemical parameters and flavonoids quantifications of the methanol extract of leaves of the MF1 fraction from $R$. discolor determined by UPLC-MS chromatography.

\begin{tabular}{lccccc}
\hline \multicolumn{1}{c}{ Compounds } & $\begin{array}{c}\text { Chemical } \\
\text { Formula }\end{array}$ & $\begin{array}{c}\text { Parent ion } \\
\left(\boldsymbol{m} / \boldsymbol{z}^{\mathbf{2}}\right.\end{array}$ & $\mathbf{R T}^{\mathbf{1}}(\mathbf{m i n})$ & $\begin{array}{c}\text { Concentration } \\
(\mathbf{m g} / \mathbf{m L})\end{array}$ & $\begin{array}{c}\text { Percentage } \\
\text { of presence } \\
(\boldsymbol{\%})\end{array}$ \\
\hline Luteolin-7-glucoside & $\mathrm{C}_{21} \mathrm{H}_{20} \mathrm{O}_{11}$ & 448 & 6 & 0.0735 & 15 \\
Kaempferol & $\mathrm{C}_{15} \mathrm{H}_{10} \mathrm{O}_{6}$ & 286 & 8.9 & 0.3675 & 75 \\
Isoquercetin & $\mathrm{C}_{21} \mathrm{H}_{20} \mathrm{O}_{12}$ & 464 & 9.8 & 0.0245 & 5 \\
Quercetin & $\mathrm{C}_{15} \mathrm{H}_{10} \mathrm{O}_{7}$ & 302 & 10.6 & 0.0098 & 2 \\
Rutin & $\mathrm{C}_{27} \mathrm{H}_{30} \mathrm{O}_{16}$ & 610 & 11.8 & 0.0147 & 3 \\
\hline
\end{tabular}

RT: retention time, ${ }^{2}$ Parent ion $(\mathrm{m} / \mathrm{z})$ : molecular ions of the standard compounds (mass to charge ratio)

The human influenza A/H1N1 strain outbreak of swine-origin, in 2009, became a serious public concern around the world [46-48]. Out of this necessity to create a new antiviral medicine, an important alternative has been the use of medicinal plants for their content in chemical compounds such as secondary metabolites [49]. In this broad group of medicinal plants we find Rhoeo discolor, which is a traditional medicinal plant used to treat fever, the common cold, headache, and limb pain [18]. However, its mechanism of inhibition of viral replication has not been reported, thus far. In this study, $R$. discolor displayed inhibitory effects on a broad spectrum of influenza virus A strains. To explore the antiviral mechanism of $R$. discolor, we treated MDCK cells with $R$. discolor during different stages of viral replication in a time of addition assay. $R$. discolor did not inhibit viral replication when added before viral adsorption (Table 1). These results indicated that the extracts or fractions may not contain secondary metabolites, and that they can interact with the sialic acid receptor that prevents their entry, and thus the replication of the viral particle [11]. The following analysis was the post-treatment. At this level, any fractions and extracts showed the capacity for antiviral activity, and the compounds present in the fractions and in the extracts did not block the release of the progeny 
through inhibition of neuraminidase [5]. The last treatment was the co-treatment. The MF1 fraction showed activity at this level with CC50 and EC50 values of $0.90 \mu \mathrm{g} / \mathrm{mL}$ and $0.30 \mu \mathrm{g} / \mathrm{mL}$ respectively and the select index (SI) value was of 30 (SI=CC50/EC). This was the highest compared to other fractions (Table 1). This result implies that the MF1 fraction acts at the hemagglutinin level [1] and thus prevents the virus from binding to the cell surface receptors (Figure 7). As previously discussed, attachment of all influenza A virus strains to cells requires sialic acids [50]. However, there is a great number of chemically different forms of sialic acids, and the different influenza virus strains vary in their affinity to them [51].

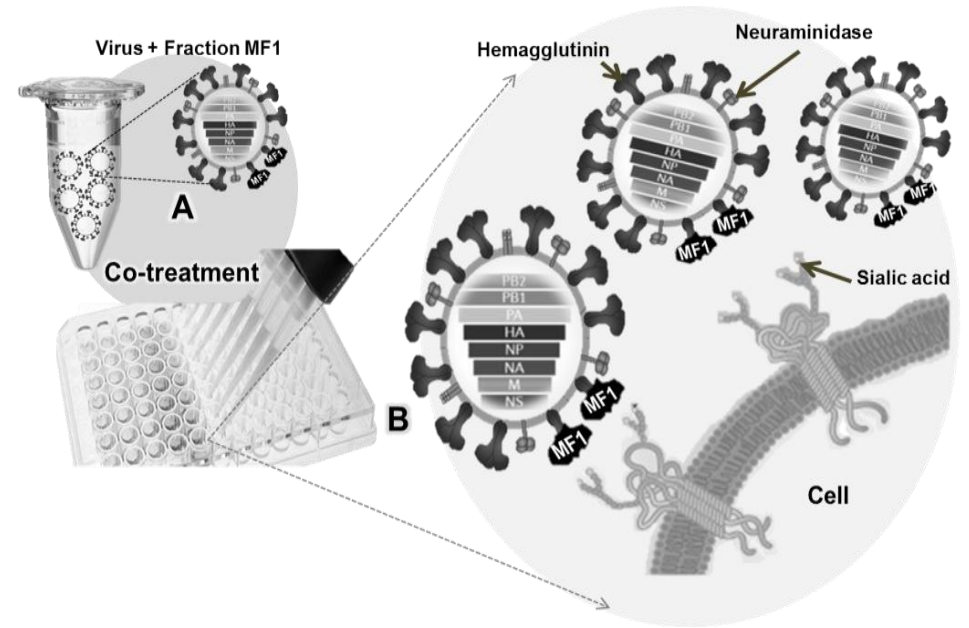

Figure 7. Mechanism of action of the MF1 fraction of interaction with the hemagglutinin of the influenza virus.

These differences may determine which animal species can be infected. For this reason, human influenza virus strains preferentially attach to sialic acids which themselves are attached to galactose by an $\alpha 2,6$ linkage $[52,53]$. In the in vitro system that we evaluated, the 6'SLN functioned as the $\alpha 2,6$ receptor $[54,55]$. Thus it was found that the MF1 fraction acts similarly to the 6'SLN compound inhibiting the hemagglutinin which, in this study, was confirmed by the identification and quantification of the NP gene.

In this phytochemical study we found the presence of five secondary metabolites that correspond to the group of flavonoids. The flavonoids were kaempferol, quercetin, isoquercetine, rutin, and luteolin-7-glucoside, and they can be responsible for the antiviral activity such as reported by Orhan et al. [14]; Zhang et al. [15]; Sithisarn et al. [16]; Jeong et al. [41]. Isoquercetin and quercetin have been reported in other studies $[58,59,60]$ for their inhibition of the replication of the influenza virus. It is noteworthy that flavonoids are within the most abundant compounds in commelinaceae, according to various reports [28,61,62,63,64]. Meanwhile, Yang et al. [65] demonstrated through in vitro evaluations of the different chemical structures of secondary metabolites, present in green tea, against the influenza virus, such as rigid flavonols (for example kaempferol), show much stronger inhibitory effects due to the presence of a double bond, of $\mathrm{C} 2-\mathrm{C} 3$ and a ketone in C-4, and the hydroxy functionality at the C-4' position in ring B. These flavonoid structures are present in the MF1 fraction of the methanol extract from the leaves of $R$. discolor, as shown in the Figure 6. Also, the presence of more $\mathrm{OH}$ groups in the Bring of flavonoids reduced their NA inhibitory effect. But the presence of more hydroxyl groups in the A or B-ring and glycosylations of flavones and flavonols is essential in order to exhibit their potent inhibitory activity against the H1N1 virus $[41,66,67]$. Highly hydroxylated flavonoids such as rutin and luteolin-7-glucoside were identified in the present study (Table 3 and Figure 6). 


\section{Conclusion}

The MF1 fraction from the methanolic extract of Rhoeo discolor has a strong anti-influenza activity in vitro, possibly due to the presence of kaempferol, quercetin, isoquercetin, rutin and luteolin7-glucoside. This activity may be accomplished through the suppression of the hemaglutinin. Our results provide evidence that the MF1 fraction may be considered as an alternative agent for treatment of influenza virus infections. Further studies have to be performed to evaluate in vivo the antiviral activity of $R$. discolor products.

\section{Conflict of interest}

The authors declare no conflicts of interest.

\section{Acknowledgments}

This research was supported by Project 'Infraestructura 251805' 'Consejo Nacional de Ciencia y Tecnología' (CONACyT, Mexico), Fronteras 2015-2/814 (CONACyT, Mexico) and Projects '5663.15-P and 6211.17' 'Tecnológico Nacional de México' (TecNM, Mexico). YSR and RGB acknowledges their postgraduate scholarship by the CONACyT, Mexico.

\section{References}

[1] H. J. Kwon, H. H. Kim, S. Y. Yoon, Y. B. Ryu and J. S. Chang (2010). In vitro inhibitory activity of Alpinia katsumadai extracts against influenza virus infection and hemagglutination, Virol J. 7, 307-314.

[2] C. F. Hsieh, H. R. Yen, C. H. Liu, S. Lin and J. T. Horng (2012). Ching-fang-pai-tu-san inhibits the release of influenza virus, J. Ethnopharmacol. 144, 533-544.

[3] N. Ferguson, D. Cummings, S. Cauchemez, C. Fraser, S. Riley and A. Meeyai (2005). Strategies for containing an emerging influenza pandemic in Southeast Asia, Nature. 437, 209-214.

[4] I. Longini, A. Nizam, S. Xu, K. Ungchusak, W. Hanshaoworakul and D. Cummings (2005). Containing pandemic influenza at the source, Science. 309,1083-1087.

[5] J.L. McKimm (2013). Influenza neuraminidase inhibitors: antiviral action and mechanisms of resistance, Influenza Other Respir. Viruses. 7, 25-36

[6] A. C. Hurt, T. Chotpitayasunondh, N. J. Cox, R. Daniels and A. M. Fry (2012). Antiviral resistance during the 2009 influenza A H1N1 pandemic: public health, laboratory, and clinical perspectives, The Lancet Infect. Dis. 12, 240-248.

[7] M. Kim, J. H. Yim, S. K. Kim and H. S. Kim (2012). In vitro inhibition of influenza A virus infection by marine microalga-derived sulfated polysaccharide p-KG03, Antiviral Res. 93, 253-259.

[8] M. Kim, S. Y. Kim, H. W. Lee, J. S. Shin and P. Kim (2013). Inhibition of influenza virus internalization by (-)-epigallocatechin-3-gallate, Antiviral Res. 100, 460-472.

[9] K. Kundu, M. Tyagi, B.S. Patro, S. Chattopadhyay and S.K. Nayak (2014). Synthesis and bioevaluation of some phenolic diarylpropanes as anti-cancer agents, Org. Cummun. 7, 85-97.

[10] B.F. Abdel Wahab, H.A. Mohamed and A.A. Farhat (2014). Ethyl coumarin-3-carboxylate: synthesis and chemical properties, Org. Commun. 7, 1-27.

[11] T.U. Rahman, K.F. Khattak, W. Liaqat, K. Zaman and S.G. Musharraf (2015). Characterization of one novel flavone and four new source compounds from the bark of millettia ovalifolia and in-vitro inhibition of carbonic anhydrase-II by the novel flavonoid, Rec. Nat. Prod. 9, 553-560.

[12] A. Ertaş, A.C. Gören, N. Haşimi, V. Tolan and U. Kolak (2015). Evaluation of antioxidant, cholinesterase inhibitory and antimicrobial properties of Mentha longifolia subsp. noeana and Its secondary metabolites, Rec. Nat. Prod. 9,105-115.

[13] P. Kalın, İ. Gülçin, A.C. Gören (2015). Antioxidant activity and polyphenol content of cranberries (Vaccinium macrocarpon), Rec. Nat. Prod. 9, 496-502.

[14] D. D. Orhan, B. Özçelik, S. Özgen and F. Ergun (2010). Antibacterial, antifungal, and antiviral activities of some flavonoids, Microbiol. Res. 165, 496-504.

[15] D. Zhang, X. Ji, R. Gao, H. Wang and S. Meng (2012). Synthesis and antiviral activities of a novel class of thioflavone and flavonoid analogues, Acta Pharm. Sin. B. 2, 575-580 
[16] P. Sithisarn, M. Michaelis, M. Schubert-Zsilavecz and J. Cinatl (2013). Differential antiviral and antiinflammatory mechanisms of the flavonoids biochanin A and baicalein in H5N1 influenza A virusinfected cells, Antiviral Res. 97, 41-48.

[17] P. Cos, T. Bruyne, N. Hermans, S. Apers and D. Berghe (2004). Proanthocyanidins in health care: current and new trends, Curr. Med. Chem. 11, 1345-1359.

[18] T. Rosales-Reyes, M. De la Garza, C. Arias-Castro, M. Rodríguez-Mendiola and S. Fattel-Fazenda (2008). Aqueous crude extract of Rhoeo discolor, a Mexican medicinal plant, decreases the formation of liver preneoplastic foci in rats, J. Ethnopharmacol. 115, 381-386.

[19] E. Panigo, J. Ramos, L. Lucero, M. Perreta and A. Vegetti (2011). The inflorescence in Commelinaceae. Flora-Morphology, Distribution, Functional Ecology Plant. 206, 294-299.

[20] G. Graziani, G. D'argenio, C. Tuccillo, C. Loguercio and A. Ritieni (2005). Apple polyphenol extracts prevent damage to human gastric epithelial cells in vitro and to rat gastric mucosa in vivo, Gut. 54, 193200.

[21] R. Cariño-Cortés, A. Hernández-Ceruelos, J. M. Torres-Valencia, M. González-Avila and M. ArriagaAlba (2007). Antimutagenicity of Stevia pilosa and Stevia eupatoria evaluated with the Ames test, Toxicol. in vitro. 21, 691-697.

[22] E. Idaka, T. Ogawa, T. Kondo and T. Goto (1987). Isolation of highly acylated anthocyanins from Commelinaceae plants, Zebrina pendula, Rhoeo spathacea and Setcreasea purpurea, Agric. Biol. Chem. 51, 2215-2220.

[23] M. A. D. Ortíz, S. A. Espinosa, J. F. Larios, M. D. R. Bello and J. G. L. Aguirre (2002). Elucidación estructural y actividad antimicrobiana de los metabolitos presentes en Rhoeo discolor L. Hér Hance. Tesis, Facultad de Ciencias Biológicas y Agropecuarias, Universidad de Colima, México.

[24] M. Gonzalez-Avila, M. Arriaga-Alba, M. De la Garza, M. A. Domınguez-Ortız and S. Fattel-Fazenda (2003). Antigenotoxic, antimutagenic and ROS scavenging activities of a Rhoeo discolor ethanolic crude extract, J. Toxicol. in vitro. 17, 77-83.

[25] M. Arriaga-Alba, J. L. Blasco, N. J. Ruíz-Pérez, J. Sánchez-Navarrete and R. Rivera-Sánchez (2011). Antimutagenicity mechanisms of the Rhoeo discolor ethanolic extract, Exper. Toxicol. Pathol. 63, 243248.

[26] G. Tel, B. Dogan, E. Erol, M. Ozturk, S. Nadeem, Z. Ullah, M. E. Duru and A. Duran (2016). Determination of antioxidant, anticholinesterase, tyrosinase inhibitory activities and fatty acid profiles of 10 Anatolian Klasea cass. species, Rec. Nat. Prod. 10,122-127.

[27] L.O. Demirezer, A. Büyükkaya, E. Uçaktürk, Z. Güvenal E. Palaska (2014). Adulteration determining of pharmaceutical forms of Ginkgo biloba extracts from different international manufacturers, Rec. Nat. Prod. 8, 394-400.

[28] S. V. Fowler, R. Barreto, S. Dodd, D. M. Macedo and Paynter Q. (2013). Tradescantia fluminensis, an exotic weed affecting native forest regeneration in New Zealand: Ecological surveys, safety tests and releases of four biocontrol agents from Brazil, Biol. Control. 64, 323-329.

[29] J. B. Harborne (1998). Phytochemical Methods, A guide to modern Techniques of plant analysis. In: Chapman and Hall (3rd eds). Springer, London New York, pp. 36-89.

[30] V. L. Singleton, R. Orthofer and R. M. Lamuela-Raventos (1999). Analysis of total phenols and other oxidation substrates and antioxidants by means of Folin-Ciocalteu reagent. Methods Enzymol. 299, 152178.

[31] E. W. Sim, S. Y. Lai, Y. P. Chang (2012). Antioxidant capacity, nutritional and phytochemical content of peanut (Arachis hypogaea L.) shells and roots, Afr. J. Biotechnol. 11, 11547-11551.

[32] A. Robertson and M. N. Hall (1989). A critical investigation into the flavognost method for theaflavin analysis in black tea, Food Chem. 34, 57-70.

[33] Z. Maksimović, D. Malenčić and N. Kovačević (2005). Polyphenol contents and antioxidant activity of Maydis stigma extracts. Bioresour, Technol. 96, 873-877.

[34] H. Wagner (1996). Plant drug analysis: a thin layer chromatography atlas. Springer 2, 4-5.

[35] I. Gülçin, E. Bursal, M. H. Şehitoğlu, M. Bilsel and A. C. Gören (2010). Polyphenol contents and antioxidant activity of lyophilized aqueous extract of propolis from Erzurum, Turkey, Food Chem. Toxicol. 48, 2227-2238.

[36] J. M. Rhea, M. L. Snyder, A. M. Winkler, C. Abou-Diwan and C. R. Fantz (2012). Development of a fast and simple liquid chromatography-tandem mass spectrometry method for the quantitation of argatroban in patient plasma samples, J. Chromatogr. B. 893,168-172.

[37] Parhira S, ZF Yang, Zhu GY, Chen QL, Zhou BX (2014) In Vitro Anti-Influenza Virus Activities of a New Lignan Glycoside from the Latex of Calotropis gigantean, PloS one. 9:e104544. 
[38] J. T. A. Hsu, J. Y. Yeh, T. J. Lin, M. L. Li, M. S. Wu (2012). Identification of BPR3P0128 as an inhibitor of cap-snatching activities of influenza virus. Antimicrob, Agents Chemother. 56, 647-657.

[39] S. R. Shih, J. T. Horng, L. L. Poon, T. C. Chen and J. Y. Yeh (2010). BPR2-D2 targeting viral ribonucleoprotein complex-associated function inhibits oseltamivir-resistant influenza viruses, $J$. Antimicrob. Chemother. 65, 63-71.

[40] J. M. Song, K. H. Lee and B. L. Seong (2005). Antiviral effect of catechins in green tea on influenza virus, Antiviral Res. 68, 66-74

[41] H. J. Jeong, Y. B. Ryu, S. J. Park, J. H. Kim and H. J. Kwon (2009). Neuraminidase inhibitory activities of flavonols isolated from Rhodiola rosea roots and their in vitro anti-influenza viral activities, Bioorg. Med. Chem. 17, 6816-6823.

[42] X. Xiong, S. R. Martin, L. F. Haire, S. A. Wharton and R. S. Daniels (2013). Receptor binding by an H7N9 influenza virus from humans, Nature. 499, 496-499.

[43] K. Fujii, Y. Fujii, T. Noda, Y. Muramotoa and T. Watanabe (2005). Importance of both the coding and the segment-specific noncoding regions of the influenza A virus NS segment for its efficient incorporation into virions, J. Virol. 79, 3766-3774.

[44] E. Hoffmann, G. Neumann, Y. Kawaoka, G. Hoboma and R. G. Webster (2000). A DNA transfection system for generation of influenza A virus from eight plasmids, Proc. Natl. Acad. Sci. 97, 6108-6113.

[45] E. Hoffmann, J. Stech, Y. Guan, R. G. Webster and D. R. Perez (2001). Universal primer set for the full-length amplification of all influenza A viruses, Arch. Virol. 146, 2275-2289.

[46] T. Ross, S. Zimmer, D. Burke, C. Crevar and D. Carter (2010). Seroprevalence following the second wave of pandemic 2009 H1N1 influenza, PLoS curr. 2.

[47] R. König, S. Stertz, Y. Zhou, A. Inoue and H. H. Hoffmann (2010). Human host factors required for influenza virus replication, Nature 463. 813-817.

[48] V. Karthick, K. Ramanathan, V. Shanthia and R. Rajasekaran (2013). Identification of Potential Inhibitors of H5N1 Influenza A Virus Neuraminidase by Ligand-Based Virtual Screening Approach, Cell Biochem. Biophys. 66, 657-669.

[49] N. Sriwilaijaroen, S. Fukumoto, K. Kumagai, H. Hiramatsu and T. Odagiri (2012). Antiviral effects of Psidium guajava Linn. (guava) tea on the growth of clinical isolated H1N1 viruses: Its role in viral hemagglutination and neuraminidase inhibition, Antiviral Res. 94, 139-146.

[50] A. Pekosz, C. Newby, P. S. Bose and A. Lutz (2009). Sialic acid recognition is a key determinant of influenza A virus tropism in murine trachea epithelial cell cultures, Virol. 386, 61-67.

[51] J. M. Nicholls, R. W. Chan, R. J. Russell, G. M. Air and J. S. Peiris (2008). Evolving complexities of influenza virus and its receptors, Trends Microbiol. 16, 149-157.

[52] H. Wan and D. R. Perez (2006). Quail carry sialic acid receptors compatible with binding of avian and human influenza viruses, Virol. 346, 278-286.

[53] X. Sun, Y. Shi, X. Lu, J. Hea and F. Gao (2013). Bat-derived influenza hemagglutinin H17 does not bind canonical avian or human receptors and most likely uses a unique entry mechanism, Cell Reports. 3, 769-778.

[54] M. A. Mohsin, S. J. Morris, H. Smitha and C. Sweet (2002). Correlation between levels of apoptosis, levels of infection and haemagglutinin receptor binding interaction of various subtypes of influenza virus: does the viral neuraminidase have a role in these associations, Virus Res. 85, 123-131.

[55] M. Imai, T. Watanabe, M. Hatta, S. C. Dasa and M. Ozawa (2012) Experimental adaptation of an influenza H5 HA confers respiratory droplet transmission to a reassortant H5 HA/H1N1 virus in ferrets, Nature. 486, 420-428.

[56] G. B. Zhang, F. H. Bing, J. Liu, Z. Li and Y. F. Liao (2010). Effect of total alkaloids from Commelina communis L. on lung damage by influenza virus infection, Microbiol. Immunol. 54, 754-757.

[57] J. C. Kash, Y. Xiao, A. S. Davis, K. A. Walters and D. S. Chertow (2014). Treatment with the reactive oxygen species scavenger EUK-207 reduces lung damage and increases survival during 1918 influenza virus infection in mice, Free Radical. Biol. Med. 67, 235-247.

[58] P. Kumar, S. Sharma, M. KhannaA and H. G. Raj (2003). Effect of Quercetin on lipid peroxidation and changes in lung morphology in experimental influenza virus infection, Int. J. Exp. Pathol. 84, 127-134.

[59] P. Kumar, M. Khanna, V. Srivastava, Y. K. Tyagi and H. G. Raj (2005). Effect of quercetin supplementation on lung antioxidants after experimental influenza virus infection, Exp. Lung Res. 31, 449-459.

[60] Y. Kim, S. Narayanan and K. O. Chang (2010). Inhibition of influenza virus replication by plantderived isoquercetin, Antiviral Res. 88, 227-235.

[61] M. A. Del Pero Martínez and T. Swain (1985). Flavonoids and chemotaxonomy of the Commelinaceae, Biochem. Syst . Ecol. 13, 391-402. 
[62] J. Z. Stirton and J. B. Harborne (1980). Two distinctive anthocyanin patterns in the Commelinaceae, Biochem. Syst. Ecol. 8, 285-287.

[63] M. A. Del Pero Martínez and A. J. Martínez (1993). Flavonoid distribution in Tradescantia, Biochem. Syst. Ecol. 21, 255-265.

[64] A. Yasar, N.Ulas and S.Yildirim (2016). Microwave assisted synthesis of 2'- / 3'azaflavones/azaflavonones and their N-alkyl derivatives, Org.Commun. 9 (4), 73-81.

[65] Z. F. Yang, L. P. Bai, W. B. Huang, X. Z. Li and S.S. Zhao (2014). Comparison of in vitro antiviral activity of tea polyphenols against influenza A and B viruses and structure-activity relationship analysis, Phytother. 93, 47-53.

[66] V. M. Savov, A. S. Galabov, L. P. Tantcheva, M. M. Mileva and E. L. Pavlova (2006). Effects of rutin and quercetin on monooxygenase activities in experimental influenza virus infection, Exp. Toxicol. Pathol. 58, 59-64.

[67] K. Watanabe, R. Rahmasari, A. Matsunaga, T. Haruyama and N. Kobayashi (2014). Anti-influenza Viral Effects of Honey In Vitro: Potent High Activity of Manuka Honey, Arch. Med. Res. 5, 26-31.

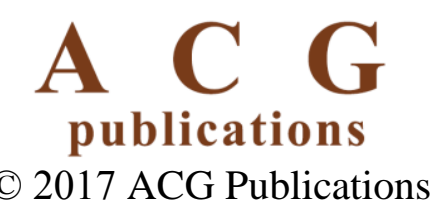

